William \& Mary Law School

William \& Mary Law School Scholarship Repository

\title{
$3-2018$
}

\section{Institutionalizing Resilience in U.S. Universities: Prospects, Opportunities, and Models}

\author{
Morris Foster \\ James O'Donnell \\ Mark Luckenbach \\ Elizabeth Andrews \\ William \& Mary Law School, eaandrews@wm.edu \\ Emily Steinhilber
}

See next page for additional authors

Follow this and additional works at: https://scholarship.law.wm.edu/facpubs

Part of the Environmental Policy Commons, and the Higher Education Commons

\section{Repository Citation}

Foster, Morris; O'Donnell, James; Luckenbach, Mark; Andrews, Elizabeth; Steinhilber, Emily; Wells, John; and Davis, Mark, "Institutionalizing Resilience in U.S. Universities: Prospects, Opportunities, and Models" (2018). Faculty Publications. 2008.

https://scholarship.law.wm.edu/facpubs/2008

Copyright c 2018 by the authors. This article is brought to you by the William \& Mary Law School Scholarship Repository.

https://scholarship.law.wm.edu/facpubs 


\section{Authors}

Morris Foster, James O'Donnell, Mark Luckenbach, Elizabeth Andrews, Emily Steinhilber, John Wells, and Mark Davis 


\section{Institutionalizing Resilience in U.S. Universities: Prospects, Opportunities, and Models}

A UTHORS

\section{Morris Foster}

Commonwealth Center for Recurrent

Flooding Resiliency, Old Dominion

University

\section{James O'Donnell}

Connecticut Institute for

Resilience and Climate Adaptation, University of Connecticut

\section{Mark Luckenbach}

Commonwealth Center for

Recurrent Flooding Resiliency, Virginia Institute of Marine Science

\section{Elizabeth Andrews}

Commonwealth Center for

Recurrent Flooding Resiliency, Virginia Coastal Policy Center, William \& Mary Law School

\section{Emily Steinhilber}

Commonwealth Center for

Recurrent Flooding Resiliency,

Old Dominion University

\section{John Wells}

Commonwealth Center for

Recurrent Flooding Resiliency,

Virginia Institute of Marine Science

\section{Mark Davis}

Tulane Institute on Water Resources Law and Policy and Tulane ByWater Institute, Tulane University

\section{Introduction}

he United States is taking a largely region-specific approach to addressing challenges posed by climate change, in contrast with national and international approaches in most of the rest of the world. In locations such as Hampton Roads, New Orleans, and coastal Connecticut, the impacts of climate change tend to be addressed as they become locally evident rather than as part of a larger anticipatory national plan. Given that regional focus, universities can play a unique role in how the United States responds to the challenges of a changing climate. Universities can be knowledge brokers positioned outside or across political, jurisdictional, and agency boundaries (localities, states, and federal) that often are problematic for regional planning and action and that tend to particularize rather than generalize knowledge. Universities have the capacity to translate that knowledge from local cases to politically and culturally contextualized states to global generalizations.

Another of the central challenges presented by climate change is that the physical processes involved, as well as their multiple consequences, require time scales of decades and centuries to develop and implement effective adaptation and mitigation strategies (Stehr \& Vonstorch, 1995). In contrast with political election cycles (of 2 and 4 years) and business depreciation schedules (typically of 5-20 years), universities are among the few U.S. social institutions that intentionally plan for a century and beyond, a time scale sufficient to assess the ongoing impacts of climate change.
At the same time, responses to climate change also require the application of diverse bodies of knowledge and disciplinary skills to engage with a phenomenon that has implications for all aspects of life on this planet. Alone among U.S. public institutions, universities aspire to assemble and synthesize "universal" knowledge across the multiple fields and disciplines that are needed to address those pervasive implications.

Thus, universities may be uniquely positioned to innovate and model the ways in which other U.S. social institutions can internalize long-term responses to a changing physical environment from multidisciplinary and local-to-global perspectives. Universities are just now beginning to incorporate that broader enterprise of resilience-defined, generally, as the ability of physical, ecological, and social systems to absolve, deflect, or resist the disruptive impacts of climate change, as well as to adapt to and recover from those ongoing perturbationsinto their core missions of scholarship, teaching, and outreach. Arguably, how they do so may presage the ways in which the United States deals with the consequences of climate change for decades to come.

In what follows, we consider key implications of that prospect, primarily from the perspective of coastal resilience, as climate-induced sea level rise increasingly disrupts the multiple complex systems affected by land-sea interactions. 


\section{Generalizable Knowledge}

Whereas individual scientists and scholars working on resilience tend to focus on case studies and empirical data that inform the fundamental development of general theories (Wise et al., 2014), universities as institutions have taken a more applied practicebased approach, facilitating planning and evaluation of local projects intended to increase resilience to manifestations of climate change already evident in their regions. Universities with coastal resilience initiatives, for example, are undertaking projects that respond to local priorities for targeted interventions in areas such as risk communication (Covi \& Kain, 2016), socioeconomic vulnerability to storm surges (Liu et al., 2016), critical habitat loss (Kirwan \& Megonigal, 2013), and fisheries impact (Sumaila et al., 2011).

Academic resilience projects often take existing technologies and methods and apply those to real-world problems resulting from climate change. Those projects also often require working with community stakeholders for planning, design, and implementation, as social and cultural contributors can be just as significant as physical contributors in resilience outcomes (Adger et al., 2013). Thus, whereas science and engineering innovations are a necessary part of resilience, so too are the translation of innovation to practice and the social science of stakeholder and community engagement. Much of what is generalizable as resilience research will be developed in those latter two areas.

The authority that universities can bring to resilience efforts depends in large part on their reputations for the objective analysis and evaluation of generalizable knowledge. The increasing pace of climate change will place a premium on having an openly available literature that provides worldwide access to evidence-based, state-of-the-art technologies, strategies, and methods for mitigating and adapting to climate change as those are developed and validated. In building that resilience literature, universities have the unique role of verifying the globally applicable "science" of resilience by supporting a transparent peer review process.

\section{Academic Trajectory}

Schools of public health may be an existing academic model for the path that resilience might take as it is institutionalized in universities. In the 19th century, prior to the establishment of university-based schools, public health in the United States largely had comprised local efforts to improve sanitation practices and infrastructure in response to periodic epidemics of infectious diseases such as yellow fever and cholera. Those interventions often were as politically controversial in the 19th century as adaptation and mitigation for climate change are in the United States in the 21 st century. Schools of public health emerged in the United States in the early 20th century through a combination of a growing demand for public health workers as well as for national standards for their training, the increasing focus of medical training on biological rather than social aspects of health, the prioritization of academic theory building over outcomes-based applications in traditional social science disciplines, and the need for community- and populationbased perspectives on health (Duffy, 1992).

Like public health in the last century, public resilience is emerging as a discipline from the earth sciences, social sciences, systems engineering, and law and policy. Also like public health, this emerging academic domain is based largely on local and regional efforts to develop interventions focused on prevention (informed by quantitative analytics and stakeholder engagement) that are designed to optimize the application of current best practices and technologies for enhancing community resilience. Although resilience, as also public health, may be the site for methodological and theoretical innovations, the ultimate metric will be measurable improvements in quality of life. Building a portfolio of evidence-based interventions and a workforce to implement those will resonate more loudly at the institutional level than will building an academic resilience theory, even though the latter will advance the former.

\section{Funding and Sustainability}

For the moment, resilience remains an area in which reactions to events like Hurricanes Katrina and Sandy drive the U.S. research agenda because their aftermaths set funding priorities as well as local and state agendas for their public research universities. Consequently, universities located in regions facing early threats from climate change are those with the more mature resilience initiatives. At some point, though, the field will mature when long-term preparation and prevention outweigh reactions to immediate catastrophes in how funding becomes available for resilience research and applications.

Still, funding for academic resilience programs will remain multifaceted with significant support likely coming from local and state sources. To date, most academic resilience 
centers in the United States are funded primarily by institutions, philanthropic donations, and state governments. Virginia and Connecticut, for example, have established legislatively funded university-based resilience centers to provide scientific and technical assistance to localities (Virginia Chapter 440 of the 2016 Acts of Assembly, Connecticut Special Act 13-9, 2013). Ten universities in Florida have leveraged institutional and other funds to establish the Florida Climate Institute. At the same time, apart from NOAA and USGS regional centers focused on climate science in general, there is no academic network of federally funded resilience centers of excellence such as the National Institutes of Health designates and funds cancer, diabetes, and other centers of excellence for health or as the National Science Foundation funds engineering research centers-nor is this likely to change in the foreseeable future due to the partisan nature of climate change as a topic in public discourse. The lack of centralized federal designation and funding in the United States has the advantages of each university developing resilience emphases that are more closely tailored to regional issues, of resilience being more likely to spread across multiple departments and colleges rather than being isolated in a stand-alone center or institute that is in turn focused on satisfying the uniform requirements of the federal agency that funds it, and of university resilience efforts developing sustainable internal funding models.

The most sustainable model for resilience in a university setting will likely be through tuition for certificates and degrees in emerging resilience-related skills and competencies supplemented by research grants, which is the traditional disciplinary- specific academic business model. This sustainability strategy likely will lead university-based resilience initiatives to develop workforce training programs faster than a path via dedicated research centers and also to constitute resilience as an academic school like public health that can control its own academic degree programs rather than persist as an interdisciplinary collaboration dependent on the good will of other schools and colleges within the university.

\section{Universities as Public Conveners}

Although it often is said that social institutions in the United States have become politicized, universities nonetheless retain a greater ability than others for scientific authority as well as for public trust (Pew Research Center, 2016). In addition, universities are not constrained by the arbitrary and confusing geography of political boundaries, and so often can address regional issues and interests that otherwise are fragmented by multiple political subdivisions. That greater geographic reach is matched by greater chronological reach, as universities have a capacity for longerterm planning and perspectives on issues like climate change that have much shorter-term political horizons. Universities are proving to be useful platforms for regional dialogues about resilience that require conversations across political jurisdictions, levels and agencies of government (local, state, and federal), and different time horizons. The need for that functionality is likely to increase over time as planning for resilient adaptations to widening effects of climate change requires greater coordination.
Old Dominion University, for example, convened a 2-year intergovernmental pilot project (IPP) to create a framework for intergovernmental planning for sea level rise and recurrent flooding in a region composed of 17 localities and 24 federal facilities (Steinhilber et al., 2016). More than 300 unique participants representing 11 federal agencies and six state agencies along with municipalities, nonprofits, private sector partners, and other stakeholders took part. A primary lesson of the IPP was the extent of the jurisdictional and procedural complexities involved in assembling working groups across such a diverse but necessary collection of organizations, let alone reaching consensus about specific recommendations for the region and then implementing those.

\section{Economic Development}

If climate change has the magnitude of societal impacts that the science predicts, then resilience will become a pervasive knowledge-based activity across many if not all economic sectors. Universities will be key players in training and credentialing that workforce, which is why certificate and degree programs are likely to become the primary business model for growing and sustaining resilience as part of the academic enterprise. Universities also can become central in building regional economic clusters based on resilience innovations and applications (Filer, 2017). For example, water technology clusters are emerging in New Orleans, Miami, and Virginia's Hampton Roads with the engagement of local research universities because of the high vulnerability of those regions to sea level rise. Milwaukee is developing 
a cluster focused on water quality, and Nevada is developing one on water conservation, both with key university involvement.

Resilience, though, can benefit all economic sectors and clusters by slowing the growth of maintenance costs due to climate change and reducing the risks that climate change imposes on investment decisions. Ultimately, resilience as a set of evidencebased practices and technologies will become more effective in helping us deal with the effects of climate change as those practices and technologies become more engrained in everyday economic activities. In the absence of a coordinated federal effort, universities will play a central role in innovating and evaluating resilient practices and technologies that reduce costs and risks across all sectors, in translating them into commercialize-able products and services that are integrated as agglomerative place-based economic clusters, and in training a workforce to fill the jobs that will be created in those clusters.

\section{Conclusion}

Although the phenomenon of climate change is global, the experience of U.S. universities' institutional engagement with resilience so far has had a local and regional focus. This suggests that resilience initially will develop in the United States more as a local and regional necessity in other social organizations. Subsequently, national and international standardization of workforce credentials, best practices, and other aspects of resilience must be developed and disseminated, in large part through peer-reviewed validation of generalizable knowledge generated by universities. In the meantime, though, resilience as an emerging American practice will grow through the more diverse contexts of region-specific conditions and priorities. During that growth, universities must play a unique role in facilitating the diversity of those community- and populationbased experiments in resilience in their local natural laboratories while also carrying out the academic function of generalizing resilience as a body of knowledge and theory. As a result, resilience should become more embedded within U.S. universities than other trending academic initiatives and, in turn, will embed universities more firmly in their local communities and regional economies.

\section{Acknowledgment}

This commentary benefited from discussions among participants attending Universities and Resilience: A Strategic Discussion, June 27, 2017, at Old Dominion University in Norfolk, Virginia.

\section{Corresponding Author:}

Morris Foster

Commonwealth Center for Recurrent

Flooding Resiliency, Old Dominion

University, Norfolk, VA 23508

Email: mfoster@odu.edu

\section{References}

Adger, W.N., Barnett, J., Brown, K., Marshall, N., \& O'Brien, K. 2013. Cultural dimensions of climate change impacts and adaptation. Nat Clim Change. 3(2):112-7. https://doi.org/ 10.1038/nclimate1666.

\section{Connecticut Special Act 13-9 (SB 1013).}

2013. State of Connecticut, Senate Bill no. 1013, Special Act no. 13-9. An Act Concerning Climate Change Adaptation and Data Collection. Available at: https://
www.cga.ct.gov/2013/act/sa/pdf/2013SA00009-R00SB-01013-SA.pdf. Accessed April 8, 2018.

Covi, M.P., \& Kain, D.J. (2016). Sea-level rise risk communication: Public understanding, risk perception, and attitudes about Information. Environ Commun. 10(5):612-33.

Duffy, J. 1992. The Sanitarians: A History of American Public Health. ChampagneUrbana, IL: University of Illinois Press.

Filer, L. 2017. From filling a local demand to becoming an international brand: An analysis of a water technology cluster in Hampton Roads, Virginia. CCRFR Reports. 1. http:// www.floodingresiliency.org/resources/.

Kirwan, M.L., \& Megonigal, J.P. 2013.

Tidal wetland stability in the face of human impacts and sea-level rise. Nature. 504(7478):53-60. https://doi.org/10.1038/ nature12856.

Liu, H., Behr, J.G., \& Diaz, R. 2016. Population vulnerability to storm surge flooding in coastal Virginia, USA. Integr Environ Assess. 12(3):500-9. https://doi.org/10.1002/ ieam. 1705 .

Pew Research Center. 2016. The Politics of Climate. Available at: http://assets.pewresearch. org/wp-content/uploads/sites/14/2016/10/ 14080900/PS_2016.10.04_Politics-of-Climate_ FINAL.pdf. Accessed April 8, 2018.

Stehr, N., \& Vonstorch, N.H. 1995. The social construct of climate and climate-change. Climate Res. 5(2):99-105. https://doi.org/ 10.3354/cr005099.

Steinhilber, E.E., Boswell, M., Considine, C., \& Mast, L. 2016. Hampton Roads Sea Level Rise Preparedness and Resilience Intergovernmental Pilot Project. Phase 2 Report: Recommendations, Accomplishments and Lessons Learned. Available at: http://digitalcommons.odu. edu/hripp_reports/2. Accessed April 8, 2018.

Sumaila, U.R., Cheung, W.W.L., Lam, V.W.U., Pauly, D., \& Herrick, S. 2011. Climate change impacts on the biophysics and economics of world fisheries. Nat Clim Change. 1(9):449-56. https://doi.org/10.1038/ nclimate 1301 . 
Virginia Chapter 440 of the 2016 Acts of

Assembly (HB 903). 2016. Commonwealth

of Virginia, Chapter 440, House Bill 903, An

Act to designate the Commonwealth Center

for Recurrent Flooding Resiliency jointly at

Old Dominion University, the Virginia Institute of Marine Science, and The College of

William and Mary. Available at: http://law.lis. virginia.gov/uncodifiedacts/2016/session1/ chapter440/. Accessed April 8, 2018.

Wise, R.M., Fazey, I., Smith, M.S., Park, S.E., Eakin, H.C., Van Garderen, E.R.M.A., \& Campbell, B. 2014. Reconceptualising adaptation to climate change as part of pathways of change and response. Global Environ Chang. 28:325-36. https://doi.org/10.1016/j. gloenvcha.2013.12.002. 